УДК 355.46:94(47)“1920”

DOI: $10.33099 / 2707-1383-2020-35-1-113-130$

Чірікалов О. С., кандидат історичних наук, капітан 1 рангу, доцент кафедри Військово-Морських Сил командноштабного інституту застосування військ (сил) НУО Украӥни імені Івана Черняховського (м. Київ) ORCID: 0000-0003-1939-8322

\title{
ОДЕСЬКА ЕВАКУАЦІЯ ВІЙСЬК (СИЛ) “БІЛОГО” РУХУ ТА ЦИВІЛЬНОГО НАСЕЛЕННЯ В ЛЮТОМУ 1920 РОКУ
}

У статті на матеріалах опублікованих джерел проаналізовано досвід підготовки і проведення евакуації військ (сил) “білого” руху та ичивільного населення з Одеси у лютому 1920 року.

В умовах “гібридної” збройної агресії Російської Федерачії проти України ефективне забезпечення оборони держави з морських напрямків вимагає від Військово-Морських Сил Збройних Сил України доиільних форм і способів їх застосування. В иьому контексті актуальним вважається питання підготовки та проведення евакуаційних заходів морем. Водночас зазначене можливо реалізувати після детального дослідження й узагальнення досвіду реалізації таких операцій (дій) у минулому. Саме тому автором приділено увагу підготовиі та проведенню низки евакуачійних заходів, які були здійснені командуванням “білого” руху з Одеси у лютому 1920 року під час події так званої "Громадянської війни” (1917-1920 рр.) на території України.

Автором відтворено реконструкиію перебігу подій під час підготовки і ведення евакуаційних дій, оцінено результати їх реалізації.

Виявлено та досліджено основні причини та чинники, які негативно вплинули на результати одеської евакуаиії військ (сил) “білого” руху та циивільного населення морем у лютому 1920 року. Встановлено характерні риси та особливості вказаної евакуації.

Ключові слова: евакуація військ (сил) морем, війська (сили) "білого” руху, Громадянська війна, Збройні сили Півдня Росї, Одеса, одеська евакуація 1920 року, Чорноморський театр воєнних дій. 
В умовах триваючої збройної агресії Російської Федерації проти України організація та ведення оборони країни, зокрема 3 морських напрямків, залишається надзвичайно актуальним завданням держави. Разом із тим, аналіз ситуації в районі проведення операції Об'єднаних сил, дій противника щодо дестабілізації обстановки у приморських районах, у Чорному та Азовському морях, у Керченській протоці свідчать про намагання Російської Федерації послідовно реалізувати сценарій “гібридного” вторгнення на територію України із захопленням так званого "сухопутного коридору” до Криму. Водночас унаслідок негативного розвитку подій на театрі воєнних дій не виключається можливість у необхідності проведення евакуаційних заходів, зокрема і морським шляхом.Також рівень підготовленості Військово-Морських Сил Збройних Сил України до проведення таких операцій (дій) залежить від усвідомлення уроків із цієї проблематики у вітчизняній військовій теорії, яка базується на воєнно-історичному досвіді.

У цьому контексті важливим та актуальним для сьогодення $\epsilon$ висвітлення досвіду підготовки та проведення Одеської евакуації (3-8 лютого 1920 року) - історичної події часів так званої "Громадянської війни" (1917-1920 рр.) на території України, пов'язаної з евакуацією морем із Одеси військ (сил) Збройних сил Півдня Росії (далі - ЗСПР) та Одеського гарнізону, а також цивільного на- селення з числа тих, хто не побажав залишатися на займаній Червоною армією території.

Аналіз останніх досліджень та публікацій. Проведений автором аналіз історіографічних напрацювань вітчизняної [13; 14], радянської [3; 7] і зарубіжної $[1 ; 2 ; 6 ; 17 ; 18]$ наукової спадщини, спогадів безпосередніх учасників подій $[4 ; 10]$ свідчить, що проблематика дослідження висвітлена фрагментарно та у прямій постановці не розглядається. Разом із тим, необхідно відмітити сумісну працю Дж. Русселла та Р. Кона [12], в якій детально реконструйовано перебіг подій під час евакуації військ (сил) “білого" руху та цивільного населення у лютому 1920 року з Одеси. Водночас у дослідженні акцент робиться на висвітленні перебігу евакуаційних заходів. Отож, комплексне вивчення проблеми залишилося поза увагою істориків, автором не виявлено цілісного, грунтовного та об'єктивного воєнно-історичного дослідження з цієї тематики.

Отже, мета статті полягає у розкритті та узагальненні досвіду підготовки та проведення евакуації військ (сил) “білого" руху та цивільного населення у лютому 1920 року з Одеси для його використання у процесі вдосконалення теорії і практики діяльності ВійськовоМорських Сил Збройних Сил України.

Виклад основного матеріалу дослідження. Наприкінці 1919 р. обстановка на південному фронті для військ ЗСПР була напруженою: в результаті контрнаступу Південного фронту Червоної армії, що розпочався в жовтні 1919 р., війська 
“білих” були відкинуті на південь, а до 9 січня 1920 р., коли противнику вдалося вийти до узбережжя Азовського моря та оволодіти Ростовом-на-Дону - остаточно розсічені на дві частини. Отже, війська Київської групи ЗСПР виявилися відрізаними від основних баз і центрального командування [14].

Реагуючи на зміни в обстановці, ще 17 грудня 1919 р. Головнокомандувачем ЗСПР генерал-лейтенантом А. I. Денікіним було прийнято рішення щодо підпорядкування військ Київської групи та всіх інших частин, що знаходилися на заході, командувачу військами Одеського округу генералу М. М. Шиллінгу, головним завданням яких було прикриття Північної Таврії та Криму з одночасним відведенням військ на лівий берег Дніпра (телеграма Головнокомандувача ЗСПР від 23 грудня 1919 р. № 01739) [2, c. 240; $12 ; 13 ; 15$, с. 122]. Оцінивши обстановку та прогнозуючи розвиток подій на фронті не на свою користь, генерал М. М. Шиллінг у своїй телеграмі від 22 грудня 1919 р. № 017344 начальникам англійської та французької місій зазначав, що “для обеспечения операции и морального спокойствия войск и, главное, на случай неудачи необходимо: обеспечение эвакуации Одессы союзным флотом и союзным транспортом; право вывоза семейств и лиц, оставление которых грозило им опасностью; право прохода в Румынию войск, подвижных составов и технических средств" $[1$, с. $470 ; 4 ; 5 ; 18$, с. 278]. Крім цього, 24 грудня у своєму листі до начальника британської місії в Одесі (№ 0512 від 24 грудня 1919 р.) він також вказував на необхідність “... содействия союзников по вывозу семейств офицеров и гражданских служащих Добрармии...” та “...пропуска в Бессарабию части одесского гарнизона в случае невозможности посадить его на суда..." [10, с. 43; 13]. У відповідь на листа начальник британської місії повідомив, що “...вопрос о восстановлении Бугазского моста не может быть решен в Константинополе, и запрос послан в Париж..." та “для вывоза семей военнослужащих и лиц, сочуствующих Добрармии, будут присланы суда в количестве, необходимом для вывоза 30 тыс. человек" $[13 ; 15$, с.123; 18, с. 278]. Отож, робота 3 планування евакуації військ із Одеси поступово розпочалася. Однак вже 31 грудня 3 причин політичного характеру генерал А. І. Денікін віддав нову директиву, в якій вказував на важливість утримання Одеського району, пошук можливостей виконання цього завдання без шкоди для оборони Криму. Водночас він зажадав від командування англо-французьких військ гарантії їх допомоги в евакуації Одеси в разі неможливості її утримання [2, с. $241 ; 18$, с. 278]. Проте оскільки одним iз пріоритетних завдань для ЗСПР та союзників стала саме оборона Одеси, процес планування евакуації з цього району був призупинений.

3 отриманням директиви, генерал М. М. Шиллінг провів перегрупування військ із метою прикриття Криму, 
Північної Таврії та безпосередньо Одеси. Одночасно він доповідав командуванню, що в разі негативного перебігу подій на фронті, кількість людей і матеріальних засобів, які необхідно буде евакуювати, значно зросте. У зв'язку з цим він наполягав на тому, що оскільки в цьому випадку повна евакуація морем може виявитися нездійсненною навіть за сприяння союзників, необхідно заздалегідь розглянути можливість евакуації військ і біженців суходолом в Румунію, для чого просив отримати через союзне командування дозвіл на пропуск через Бессарабію [2, с. 241-242; 14; 18, c. 278]. 3 січня 1920 р. М. М. Шиллінг отримав телеграму № 84/109, в якій йшла мова про те, що “...по заявлению англичан, они обеспечат эвакуацию раненых и больных, а также семейств офицеров; что же касается гражданского населения, то таковое необходимо будет отправить сухим путем в Румынию..." [1, c. $474 ; 4 ; 5 ; 7$, с. $738 ; 13]$. Однак робота щодо надання дозволу на пропуск через Бессарабію союзним командуванням організована не була.

8 січня 1920 р. начальник британської місії відправив листа до генерала М. М. Шиллінга (№ 41), в якому повідомляв, що “...Одессе опасность не предвидится, ...для эвакуации 30 тыс. человек пароходов представлено не будет, а если бы таковые и были, то возникает затруднение в принятии их в другие страны" [5; 13; 18, с. 279]. У відповідь М. М. Шиллінг направив листа (від 10 січня 1920 р. № 0949), в якому наполягав на точному з'ясуванні пи- тання "на что мы можем рассчитывать со стороны союзников в отношении средств эвакуации ", проте відповіді він не отримав [13].

На лист генерала М. М. Шиллінга начальнику британськї місії від 16 січня № 010066, в якому він вимагав категоричної відповіді на питання щодо допомоги у проведенні евакуаційних заходів у зв'язку з можливою втратою Одеси, також конкретної відповіді отримано не було [13; 18, с. 279]. Проаналізувавши обстановку, М. М. Шиллінг направив донесення генерал-лейтенанту А. І. Денікіну, в якому вказував на "необходимость принятия экстренных мер и самого срочного направления транспортов, угля и военных судов". Начальника британської місії у своєму листі (від 19 січня 1920 р. № 0231356/01122) він також просив: “...выслать более мощные военные суда; транспорты для больных, раненых и семей; ускорить прибытие угля; ускорить получение разрешения румын на постройку переправ у намеченных пунктов переходов через Днестр" [7, с. 740; $13 ; 18$, с. 280]. Оцінивши обстановку на фронті, М. М. Шиллінг дійшов висновку щодо скорішої втрати Одеси та що “...на эвакуацию морем рассчитывать нельзя", які він виклав у своїх доповідях А. І. Денікіну (від 22 січня № 001195 та від 23 січня № 01196) [13]. Однак донесенням М. М. Шиллінга не було приділено належної уваги, а його пропозиції залишилися без реалізації.

Водночас у доповідях М. М. Шиллінга керівництву про поточну обстановку спостерігалося протиріччя: гене- 
рал повідомляв, що на півдні України бойові дії ведуться цілком успішно та, відповідно, Одесі найближчим часом ніщо не загрожує, тобто доповіді носили цілком оптимістичний характер. Враховуючи зазначене, командування союзників робило в першу чергу акцент на питаннях оборони Криму, втрата якого здавалася більш імовірною, у зв'язку з чим було здійснено перерозподіл наявних сил та засобів на морі. Так, англійське командування наприкінці січня 1920 р. дало наказ усім своїм транспортним суднам та декільком військовим кораблям у регіоні припинити виконання всіх завдань та прибути до Севастополя для забезпечення евакуації. Представництво союзників в регіоні, обгрунтовуючи таке рішення тим, що “сумнівається в можливості втрати Одеси" [4; 5], 21 січня 1920 р. все ж повідомило генерала М. М. Шиллінга про готовність у разі необхідності надати допомогу в реалізації евакуаційних заходів [5; 14].

Що стосується дій “білого” флоту, то на той час командування ЗСПР у зв'язку з виходом частин Червоної армії в перших числах січня до берегів Азовського моря, зосередило свою увагу на проведенні евакуаційних заходів iз Маріуполя, Херсона, Миколаєва та інших портів, для чого були залучені всі наявні кораблі флоту, криголами та запаси вугілля [5]. У підсумку всі плавзасоби з Миколаєва вивести не вдалося - були залишені три десантних судна типу "Ельпідіфор", підводні човни типу “АГ”, підводний човен “Нерпа” та декілька недобудованих катерів. Водночас до Одеси було відведено крейсер “Адмирал Нахимов”, ескадренні міноносці “Цериго” і “Занте”, десантні судна типу “Ельпідіфор” (№ 413 та № 414), два підводні човни, транспорт “Дон” [15, с. 126]. Невдало була проведена евакуація родин добровольців із Херсону - внаслідок відсутності криголамів та буксирів завантажені транспорти стали в гирлі Дніпра, зазнали нападу махновців, через що біженці були вимушені рухатися пішки до Криму та Одеси [13].

Отож, в Одесі на той час не залишилося достатньої кількості плавзасобів для проведення повномасштабної евакуації морем. Наприкінці січня 1920 р. спостерігалася певна розпорошеність сил і засобів "білих" та їх союзників на морі [15, с. 125]. Крім цього, за спогадами А. І. Денікіна [4], “морское командование в Севастополе, которому приказано было послать все свободные суда в Одессу, как оказалось впоследствии, саботировало и одесскую и новороссийскую эвакуацию, под разными предлогами задерживая суда... на случай эвакуации Крыма".

Протягом січня М. М. Шиллінг намагався спланувати заходи щодо забезпечення евакуації та відводу військ до Бессарабії, направляючи чисельні телеграми командуванню союзників, французьким та румунським представникам, командувачу Чорноморським флотом, начальнику морського порту, командиру британського крейсера “Ceres” [7, с. 740-741; 13]. Однак часу 
на прийняття обгрунтованих та реалістичних рішень вже не вистачало.

Обстановка на південному фронті для ЗСПР набувала катастрофічного характеру: вже 29 січня 14-а армія “червоних" зайняла Херсон, а наступного дня - Миколаїв; унаслідок ударів 12-ї радянської армії угруповання військ генерал-лейтенанта М. Е. Бредова оказалось відрізаним від Одеси та отримало наказ відступати до Румунії [5; 14]. Загону полковника О. А. Стесселя ставилося завдання щодо прикриття безпосередньої евакуації Одеси; англійське морське командування надавало гарантії, що зазначений загін буде вивезено "в останню мить на військових кораблях під прикриттям корабельної артилерії" [4; 12]. Отож, стало зрозуміло, що довготривала оборона Одеси неможлива.

31 січня 1920 р. генерал М. М. Шиллінг направив у Ставку, а 1 лютого - начальнику англійської місії - телеграму, в якій за результатами аналізу обстановки робив висновки щодо неможливості подальшого утримання Одеси [2, с. 244; 14]. Саме тоді після особистої доповіді начальника штабу М. М. Шиллінга, генерала В. В. Чернавіна про стан справ, начальник флоту адмірал Д. В. Ненюков усвідомив реальну ситуацію навколо Одеси та необхідність вжити термінові заходи щодо спрямування наявних плавзасобів для організації евакуації морем. Про обстановку, яка склалася на одеському напрямку, було проінформовано представництво союзників у регіоні. Однак вони погодилися відправити до Одеси наряд сил та засобів тільки після отримання гарантій щодо надійності оборони Кримських перешийків. Після отримання таких гарантій англійці 3 лютого 1920 р. спрямувати до Одеси англійські транспортні судна "Rio Negro" та "Rio Pardo", пароплав із запасом вугілля та крейсер "Cardiff". Зі складу Чорноморського флоту адмірал Д. В. Ненюков виділив для евакуації пароплави "Святой Николай” та “Николай” (№ 119); крім того, додатково планувалося залучити допоміжний крейсер "Цесаревич Георгий”, міноносець “Жаркий” та транспортні судна [2, с. 244-245; 3, с. 689-690; 12; 15, c. 126-127].

Тим часом події на фронті розвивалися динамічно: 2-й корпус "білих" не зміг утримати позиції та розпочав відхід до Одеси, 3 лютого підрозділи 41-ї стрілецької дивізії “червоних” зайняли Очаків, а їх головні сили у складі 41-ї стрілецької дивізії, підсиленої 1-ї бригади 45-ї дивізії та кавалерійської бригади розпочали наступ на Одесу [2, с. $245 ; 5$; $12 ; 16 ; 17$, с. 300]. На той час в Одесі залишилися в основному тільки розрізнені тилові установи військ, розташовані на півдні України, штаби, розрізнені групи військовослужбовців, які відстали від своїх частин, різні команди Української галицької армії (далі - УГА) на чолі 3 генералом В. Сокирою-Яхонтовим, добровольчі загони місцевого формування. У місті оголосили воєнний стан, а влада поспіхом формувала нові загони оборони 3 німців-колоністів, гімназистів, церковних прихожан (загін митрополи- 
та Платона), українських партизан (загін отамана Струка), робітничо-офіцерський загін [5; 6, с. 241].

Відсутність централізованого управління зазначеними загонами, загальна паніка в місті, страйки одеських робітників, збройні повстання на околицях Одеси у підсумку унеможливили створення суцільного фронту навколо міста проти “червоних". Оцінивши обстановку, генерал М. М. Шиллінг дійшов висновку щодо необхідності негайного проведення евакуаційних заходів, у результаті чого 4 лютого 1920 р. ним було віддано наказ про евакуацію Одеси [5; 6 , с. $241 ; 15$, с. $127 ; 16]$. На наступний день наказом командувача військами Одеського округу № 64 начальника гарнізону Одеси полковника О. А. Стесселя було призначено комендантом Одеського укріпленного району - начальником внутрішньої оборони міста, у підпорядкування якого переходила вся військова та цивільна влада в місті. Одночасно був створений штаб оборони міста, до завдань якого входило утримання Одеси до тих пір, поки “. ..останній боєцьдоброволець не буде посаджений на корабель..." [5; 7, с. 742; 13].

В умовах дефіциту часу виконання вимог наказу про евакуацію викликало необхідність здійснювати їі підготовку і проведення одночасно. Але відсутність завчасно розробленого та узгодженого плану [7, 742; 13] призвела до того, що на їі початок виявилася низка недоліків, які у підсумку вкрай негативно впливали на ефективність виконання завдань евакуації, зокрема: відомості стосовно кількості фактично задіяних в евакуаційних заходах плавзасобів були неповними; місця та порядок завантаження визначені не були; у порту було відсутнє управління рухом плавзасобів; приватні пароплави, які знаходилися в порту, не були вчасно мобілізовані управлінням військового порту Одеси та на них не були призначені військові команди, а більшість портових буксирів майже не мали військових комендантів [2, с. 246, $248 ; 12 ; 14]$.

Крім цього, евакуацію довелося розпочинати у вкрай важких умовах. Так, у ніч 34 на 5 лютого 1920 р. в робітничих районах Одеси розпочалися самочинні виступи збройних робітничих загонів, які здійснювали напади на "білих", не виходячи, утім, за межі своїх районів. Отже, більшість шляхів відходу до портів Одеси була заблокована. 3 урахуванням тяглого страйку одеських портових робітників, робота одеського порту була фактично паралізована. Це змусило полковника О. А. Стесселя виділити додаткові сили та засоби для наведення порядку силою зброї. У підсумку до 6 лютого відкриті виступи вдалося придушити, однак порядок у робітничих районах так i не був відновлений - влада ЗСПР їх не контролювала, особливо 3 настанням темряви. Портові робітники продовжували страйкувати [5; 10, с. 68-69; 13; 14$]$.

Погодні умови також були несприятливі для проведення евакуаційних заходів морем: низька температура повітря призвела до утворення плавучої криги на підходах до Одеси і в порту, що істотно ускладнювало швартові операції 
i маневрування суден у самому порту та проходження фарватерами в затоці $[2$, с. $247 ; 9$, с. 138]. Крім цього, до моменту оголошення евакуації в порту не було жодного криголама, оскільки вони ще напередодні були виведені у відкрите море для допомоги суднам, які були затиснуті кригою [14]. Пізніше відсутність криголамів у порту компенсувалася діями криголамних (“Смелый” i "Рабочий”) i великого англійського буксирів [2, с. $247 ; 5 ; 14]$. Водночас використання плавзасобів у цих умовах без підтримки криголамів призводило до збільшення витрати вугілля, якого в Одеському порту не було - останні запаси були витрачені на забезпечення експедиції з криголамів і буксирів для евакуації Миколаєва, яка була проведена напередодні евакуації Одеси [13; 14].

Отже, необхідність проведення евакуації в стислі терміни в умовах незавершеності їі підготовчого етапу з урахуванням обстановки, що склалася, вимагали, насамперед, від військового керівництва Одеси своєчасного та адекватного реагування на динамічність змін у районі проведення евакуаційних заходів, якого так і не вдалося досягнути. Плану евакуації розроблено не було, тому питання управління, взаємодії та забезпечення евакуаційних заходів вирішені не були. У підсумку управління евакуаційними процесами та контроль над ситуацією на етапі їх проведення з боку “білих" та керівництва порту практично були втрачені. Це підтверджує той факт, що у подальшому у найбільш напружені дні евакуації (7-8 лютого) частковий контр- оль за розподілом черги на швартування, проведенням суден і постановкою їх до причалів самочинно взяв на себе командир британського крейсера “Ceres” Г. О. Рейнольд (H.O. Reinold), який прибув до порту для його охорони [10, с. 74; 14].

Доречно зазначити, що на початок евакуації, крім посильного судна "Летчик”, інших російських військових кораблів в Одесі не було (допоміжний крейсер і міноносець прийшли в останні дні евакуації), тому на той час основним виконавцем евакуаційних заходів був англійський військовий флот у складі лінкора “Ауах", крейсерів “Cardiff” i "Ceres”, двох міноносців, транспортів "Rio Negro" та "Rio Pardo", які 4 лютого одразу ж приступили до евакуації військ та цивільного населення [2, с. 247, 254; 12; 14]. Цього дня евакуаційні заходи були проведені без суттєвих порушень, оскільки завантаження здійснювалося повільно та спонтанно в умовах відсутності активних дії противника. Водночас на той час вдалося вивезти морем лише невелику кількість людей (переважно цивільних) та матеріальних засобів (у тому числі військових), оскільки кількість охочих покинути Одесу була відносно невелика - більшість біженців вважала, що місто ще можливо відстояти [5].

Тоді, 5 лютого 1920 р., обстановка на підступах до Одеси для “білих” значно погіршилася - місто повністю було блоковано із суходолу, а кіннота “червоних" наблизилася до околиць на 15 км. Погіршення ситуації на фронті сприяло розповсюдженню панічних настроїв се- 
ред біженців, унаслідок чого збільшилась кількість охочих залишити Одесу. Зі свого боку це призвело до зростання інтенсивності завантаження на плавзасоби, яке здійснювалося позапланово за власною ініціативою командирів кораблів (транспортів) чи окремих командирів частин (начальників) на березі [5; 14]. Більшість плавзасобів виходили в море, намагаючись повністю заповнити евакуйованими палуби і трюми. Загалом цього дня в порту та на зовнішньому рейді за приблизними підрахунками [5; 14] знаходилася значна кількість плавзасобів - 12 пароплавів (російські “Анатолий Молчанов”, “Баку”, “Владимир”, “Дон” (несправний), “Ксения”, “Николай”, "Россия”, "Румянцев”, “Саратов”, “Тигр”, “Александрия”, болгарський “Цар Фердинанд”), 5 транспортів (російські "Грегор”, “Далланд”, “Дмитрий”, англійські "Rio Negro" та "Rio Pardo"), плавучий госпіталь "Святой Николай”, парова шаланда “Сурож”. Крім цього, у цьому районі знаходилися бойові кораблі (англійські лінкори "Ауах" та "Emperor of India", крейсери “Cardiff” і “Ceres", два міноносці, російське посильне судно “Летчик” i тральщик “Баклан”) та допоміжні судна (російські буксири "Рабочий”, “Смелый”, "Навал” та англійський вугляр "Votan"). Однак не всі транспорти, які на той час знаходилися в Одеській бухті, мали можливість узяти участь в евакуаційних заходах, оскільки через відсутність плану евакуації послідовність підходу плавзасобів та порядок їх завантаження визначено не було. Так, капітани транспортів "Rio Negro" та "Rio Pardo" одержали наказ заходити в порт для прийняття біженців тільки опівдні 6 лютого, знаходячись на рейді Одеси 34 лютого [14]. Крім цього, приватні пароплави, які знаходилися в той час у порту, підходили до пунктів завантаження самовільно, воліли брати пасажирів і вантажі тільки за плату та йшли напівпорожні або взагалі відмовлялися брати участь в евакуації [5; 15, с. 128]. Загалом евакуаційні заходи 5 лютого пройшли без суттєвих зривів.

Увечері 5 лютого 1920 р. несподівано для захисників Одеси генерал М. М. Шиллінг видав наказ, згідно якого він передавав владу в місті і захист всього півдня України військам УГА на чолі з генералом В. Сокирою-Яхонтовим [5; 6, с. 242; 13]. 6 лютого 1920 р. солдати УГА захопили всі стратегічні пункти Одеси, але забезпечити порядок у робочих кварталах не змогли. Скориставшись певним “безвладдям" у місті, зранку цього ж дня більшовики Одеси організували повстання у двох районах міста - Молдованці та Пересипі, звідки розпочали обстріл гавані з кулеметів. У порту виникла паніка $[5 ; 9$, с. $137 ; 14]$. Порядок завантаження був порушений, проте англійські транспорти продовжували брати на борт лише за спеціальними перепустками родини чинів армії та цивільних осіб, минула діяльність чи службове становище яких не дозволяло їм залишитися у “червоних"; російські транспорти приймали переважно військових, а іноземний пасажирський пароплав (імовірно болгарський “Цар 
Фердинанд”) брав на борт біженців лише за значну плату валютою [12]. До вечора 6 лютого “білим” вдалося навести відносний порядок у приморських районах Одеси та організувати завантаження в порту.

Зміни в обстановці вплинули на склад біженців - їхню більшість складали військовослужбовці ЗСПР переважно штабів, тилових частин армії, технічних військ та ті, які відбилися від своїх частин, у загальній кількості до 30 тис. осіб $[5 ; 9$, с. $138 ; 14]$. Саме тоді, у ніч з 6 на 7 лютого, генерал М. М. Шилінг зі штабом перейшов на пароплав “Анатолий Молчанов”. Евакуація штабу та керівництва Одеського гарнізону стало повною несподіванкою для захисників міста [2, c. $248 ; 12 ; 14 ; 19]$. Отож, навіть номінальне управління ходом евакуації “білими” було втрачено.

Водночас уранці 7 лютого 1920 року генерал В. Сокира-Яхонтов оголосив, що відмовляється від захисту Одеси, а о 6 годині ранку 7 лютого частини 41-ї стрілецької дивізії “червоних” увійшли до північно-східної частини міста та 3 боями стали просуватися до центру, не зустрічаючи серйозного опору [2, с. 250 ; $5 ; 14]$. Деякі частини "білих" під керівництвом полковника О. А. Стесселя не прийняли капітуляцію і розв'язали бій власне в Одесі, надаючи нападникам у деяких вузлах відчайдушний опір [5; 6 , c. 242].

У той час, поки в місті тривав бій, капітани пароплавів у порту в терміновому порядку розпочали вихід на рейд. Вийшов на рейд і пароплав “Анатолий
Молчанов”, на борту якого перебували генерал М. М. Шилінг та кілька сотень осіб конвою командувача [2, с. 249-250; 8]. Завантаження залишків військових частин ЗСПР здійснювалося на борт російського пароплава "Владимир". За порядком у порту стежили юнкери Сергіївського артилерійського училища, які намагалися призупинити паніку, але безуспішно [5; 14].

Об 11 годині 7 лютого одному з “червоних" загонів вдалося вийти на височину Миколаївського бульвару, що нависає над портом i, встановивши на краю бульвару кулемети, розпочати обстріл скупчень людей в Одеському порту, який призвів до посилення паніки серед евакуйованих. Враховуючи обстановку, командир британського крейcepa “Ceres" Г. О. Рейнольд прийняв рішення закінчити евакуацію та віддав наказ всім плавзасобам о 16 годині вийти на зовнішній рейд [5]. У цих умовах більшість капітанів вивела плавзасоби в море, а декілька, зокрема англійський транспорт "Rio Negro" та пароплав Добровільного флоту “Владимир”, продовжували евакуацію, намагаючись взяти якомога більшу кількість людей. В результаті "Rio Negro" прийняв на борт подвійну проти нормального кількість пасажирів (1400 осіб), а "Владимир" взяв на борт кілька тисяч військових [2, c. $249-250 ; 12 ; 15$, с. $130-131]$.

Близько 12-ї години у результаті контратаки “білим" вдалося відкинути противника з бульвару, проте у другій половині дня загони захисників міста полковника О. А. Стесселя розпочали 
поступово відступати до порту в надії потрапити на судна, що відходили [5; 14]. Саме тоді, за розпорядженням англійського командування, крейсер “Ceres” повинен був взяти на борт юнкерів Сергіївського артилерійського училища, які прикривали порт, та старших кадетів Одеського кадетського корпусу. Після того як зазначений контингент (від 350 до 550 осіб) було прийнято на борт крейсера “Ceres” та каботажного пароплава, плавзасоби вийшли в море [5; 8]. Коли до порту для евакуації прибули офіцери із загонів полковника О. А. Стесселя, то з'ясувалося, що всупереч обіцянкам командування, суден для їх евакуації не було. Водночас частини Червоної армії і місцеві партизанські загони знову наблизилися до порту і спробували просуватися до причалів та захопити судна, але безрезультатно [2, с. $250 ; 5 ; 14]$.

Увечері 7 лютого 1920 р. із Севастополя для проведення евакуації прибули російські допоміжний крейсер “Цесаревич Георгий” та міноносець “Жаркий”, французькі броненосні крейсери “Jules Michelet" i "Waldeck Russo" та американський есмінець. В евакуації військ та біженців зазначені сили вже не змогли взяти участь, водночас вони взяли на буксир несправні судна, які знаходилися на зовнішньому рейді $[3$, с. $692 ; 4$; 10, с. $97 ; 14 ; 15$, с. 134].

Скупченість зазначених плавзасобів на рейді виникла в результаті перебігу подій. На той час в Одеському порту знаходилося декілька споруджуваних військових кораблів різного ступеня го- товності, зокрема, недобудовані крейсер “Адмірал Нахімов”, ескадренні міноносці "Цериго” і “Занте”, десантні судна типу “Ельпідіфор” (№ 413 та № 414), підводні човни "Лебідь" та "Пелікан". 3 метою недопущення їх захоплення “червоними" було здійснено низку заходів. Так, недобудований есмінець “Занте” був заздалегідь виведений з Одеського порту на зовнішній рейд і залишений на якорі без команди; вночі 7 лютого недобудований есмінець “Цериго” відтягнув на рейд буксир, звідки у подальшому він був відбуксирований до Севастополя; парова шаланда “Сурож” цієї ж ночі вивела несправний транспорт “Дон” із танками 3-го танкового загону ЗСПР i сотнями біженців на зовнішній рейд. Недобудований крейсер “Адмірал Нахімов”, десантні судна типу “Ельпідіфор" (№ 413 та № 414), підводні човни “Лебідь" та "Пелікан”, декілька несправних пароплавів, десяток немореходних буксирів і катерів вивести на рейд не вдалося $[5 ; 14 ; 15$, с. 129-130].

Заразом, бої у місті продовжувалися ще до середини дня 8 лютого 1920 року, внаслідок чого “червоним" остаточно вдалося захопити Одесу і порт. Встановивши на молах артилерійські батареї, вони спробували обстріляти 3 гармат судна, які перебували на рейді, але безрезультатно. Враховуючи малочисельність сил, які обороняли порт, англійське командування прийняло рішення закінчити евакуацію і наказало своїм кораблям ще до темряви вийти на зовнішній рейд [2, с. 248, 250]. Отже, 8 лютого 1920 р. евакуація військ та ци- 
вільного населення з Одеси офіційно закінчилася. Проте протягом ночі на дрібних плавзасобах вдалося вивезти певну кількість біженців.

9 лютого 1920 р. пароплав “Анатолий Молчанов” з генералом М. М. Шилінгом взяв курс до Криму. 3 "червоними” було встановлено перемир'я і командир американського міноносця в супроводі англійського офіцера провів переговори про евакуацію підданих цих країн, які залишилися на той час в Одесі. Протягом двох діб кораблями англійської ескадри безперешкодно була проведена евакуація населення і військ. 11 лютого, в останній день евакуації, англійські кораблі відкрили по порту вогонь, під прикриттям якого міноносці увійшли до гавані і захопили майже добудовані російські підводні човни “Лебідь" та "Пелікан", вивели їх та відразу затопили на фарватері Одеського порту під приводом зробити фарватер непрохідним [2, с. 256-257; 5; 18, с. 282]. На цьому евакуація військ (сил) і цивільного населення з Одеси закінчилася. Деякі пароплави приватних товариств відбули до Варни; більшість неморехідних і дрібних суден попрямували до Суліни; транспорти "Rio Negro" та "Rio Pardo" відбули до Константинополя; військові кораблі та транспорти - до Севастополя [5]. Усі плавзасоби успішно прибули до пунктів призначення.

Що стосується тих, хто не зміг евакуюватися і не бажав залишатися в зайнятій більшовиками Одесі, то вони організувалися в загони (від 12 до 16 тис. осіб), а потім відійшли частинами в двох напрямках: до Овідіополя, сподіваючись на притулок у Румунії, та до Тирасполя, намагаючись з'єднатися з корпусом генерал-лейтенанта М. Е. Бредова, який відступав до Польщі $[5 ; 6$, с. 242; 11, с. 59; 14; 19]. Доля тих, хто відійшов до Овідіополя, склалася трагічно - не будучи пропущеними румунською владою на їх територію, значна частина потрапила в полон Червоній армії, багато загинуло в бою чи покінчили життя самогубством. Лише декільком сотням вдалося переправитися до Румунії [5; 11, с. 59; $14 ; 18$, c. 282].

3 урахуванням того, що плавзасоби з Одеси попрямували до різних портів, а багато біженців евакуювалися приватно, загальну кількість евакуйованих встановити важко: за різними оцінками [2, с. $257 ; 15$, с. 134] вона склала до 15 тис. осіб (з них близько 3 тис. поранених та хворих [13]) із майже 40 тис. охочих, тобто 37,5 \%. 3 військової техніки, спорядження та матеріальних запасів вдалося евакуювати всі танки, які прибули в Одесу з Миколаєва, майже всі справні бронеавтомобілі, частину обладнання технічних військ, автомобілів та авіаційного майна [13]. За доповіддю генерала М. М. Шилінга [7, с. 743-744; 13], в Одесі було залишено близько 300 хворих, бронепотяги, бойові припаси на баржах, частина вантажних та легкових автомобілів, усіх коней, недобудований крейсер “Адмирал Нахимов”, міноносець “Занте” та два затоплених підводних човни, декілька дрібних суден та буксири, частину родин добровольців та цивільних працівників Добрармії. 
За повідомленням командувача 14-ї армії “червоних", в Одесі було взято в полон три генерали ЗСПР, близько двохсот офіцерів та 3 тис. солдатів (у тому числі в госпіталях 1,5 тис. хворих і поранених), захоплено понад 100 гармат різних калібрів, 4 бронепотяги (згідно [17, с. 301] до 200 гармат та 5 бронепотягів), 4 бронеавтомобілі, кількасот тисяч снарядів і патронів, склади інженерного, автомобільного, авіаційного та іншого майна і продовольства, недобудований крейсер “Адмирал Нахимов”, два десантні судна типу “Ельпидифор” (№ 413 та № 414), пароплав “Александрия”, декілька невеликих пароплавів, які потребували ремонту, та десяток неморехідних буксирів і катерів. В Одеському порту та Карантинній гавані залишилися невивезеними понад 350 тис. пудів зерна, 3 тис. пудів кам'яного вугілля, декілька англійських мотоциклеток $[5 ; 13 ; 16 ; 17$, c. 301]; залізничні шляхи були забиті потягами з різноманітними вантажами, евакуйованими з Києва та півдня України, зокрема було залишено 130 тис. пудів дров [2, с. 257-258; 5]. Крім цього, як зазначалося вище, багато загиблих і полонених було в “овідіопольському" загоні, особовий склад якого також не зміг евакуюватися морем і прямував суходолом до кордонів Румунії.

Висновки дослідження. Таким чином, евакуація військ (сил) “білих" та цивільного населення з Одеси у лютому 1920 р. була проведена у формі дій з евакуації, які за своїми результатами слід вважати невдалими.
На думку автора, незадовільна реалізація евакуаційних заходів сталася внаслідок безініціативності та неорганізованості командування “білих" під час підготовки та проведення евакуації, що фактично призвело до втрати ними управління на зазначених етапах.

Розглянута евакуація мала низку особливостей. Так, на той час у Чорному морі флот “білих" мав повну перевагу в силах та засобах над противником і панував на морі, а наявна авіація “червоних" не мала достатніх спроможностей щодо ведення контревакуаційних заходів. Отож, основну загрозу для евакуйованих, насамперед, представляли дії противника на суходолі. В Одесі командування "білих" не змогло своєчасно ні організувати зовнішню оборону міста, ні забезпечити порядок у самому місті, що у підсумку призвело до втрати контролю над ситуацією в районі проведення евакуації, i, як наслідок, перехопленню та утриманню ініціативи противником навіть в умовах кількісно-якісної переваги “білих" над “червоними”. В цьому ж контексті необхідно зазначити участь в евакуаційних заходах іноземних бойових кораблів та цивільних транспортів, суден і пароплавів. Наявність лінкорів та крейсерів у складі союзних сил “білих" суттєво впливала на співвідношення бойових потенціалів протиборчих сторін не на користь "червоних", а раціональне залучення цивільних плавзасобів союзників надавало до- 
даткові можливості для завантаження більшості охочих евакуюватися. Однак ефективно використати вказані переваги під час евакуації командуванню “білих" та союзників повністю не вдалося.

Аналізуючи гідрометеорологічні умови на той час в районі Одеси, варто зазначити їх вкрай негативний вплив на процес проведення евакуації. Водночас завчасна та якісна підготовка до евакуаційних заходів дозволила б своєчасно реагувати на такі прояви погоди та певним чином компенсувати несприятливість погодних умов.

Отже, аналіз досвіду підготовки і проведення евакуації військ (сил) “білих" та цивільного населення з Одеси у лютому 1920 р. показав, що під час ведення бойових дій на приморських напрямках необхідно завчасно розглядати різні варіанти розвитку подій, зокрема можливість проведення евакуації військ (сил) та цивільного населення морем. Для успішної реалізації таких операцій (дій) надзвичайно важливою $\epsilon$ підготовленість органів військового управління та військ (сил) до їх підготовки і проведення.

Перспективами подальших наукових пошуків може бути аналіз проведення евакуації військ (сил) на Чорному морі у першій половині XX століття, визначення тенденції в розвитку застосування родів сил флотів у таких заходах.

\section{Список використаних джерел i літератури}

1. Гражданская война в России: оборона Крыма / Составитель В. Гончаров. - М.: ООО “Издательство АСТ”; СПб.: Terra Fantastica, 2003. - 534 с.

2. Гражданская война в России: Черноморский флот / Составитель В. Доценко. - М.: ООО “Издательство АСТ”, 2002. - 544 с.

3. Гражданская война на Украине 1918-1920 [в 3-х томах]. Том 2. Борьба против деникинцев и петлюровщины (май 1919 - февраль 1920 гг.) / Под ред. С. М. Короливского. - К.: Издательство “Наукова думка", 1967. - 919 с.

4. Деникин А. И. Очерки русской смуты: [Електрон. ресурс]. - Режим доступу: http://militera. lib.ru/memo/russian/denikin_ai2/5_21.html.

5. Доклад генерала Н. Н. Шиллинга генералу А. И. Деникину: [Електрон. ресурс]. - Режим доступу: https://ru.wikisource.org/wiki/ доклад.

6. Дроздов С. Эвакуация Одессы, 1920 год. Часть 64: [Електрон. ресурс]. - Режим доступу: https://www.proza.ru/2016/07/29/1217.

7. История Гражданской войны в СССР [в 5-ти томах]. Том 4. Решающие победы Красной армии над объединенными силами Антанты и внутренней контрреволюции (март 1919 - февраль 1920 гг.) / Под ред. С. Ф. Найды, Г. Д. Обочкина, А. А. Струкова и др. - М.: Государственное издательство политической лтературы, 1959. - 459 с. 
8. Как уходила из Одессы белая гвардия: [Електрон. ресурс]. - Режим доступу: https:// odessitua.com/articles/8366-kak-uhodila-iz-odessy-belaya-gvardiya.html.

9. Карпов Н. Трагедия Белого Юга. 1920 год / Н. Карпов. - М.: Вече, 2005 - 375 с.

10. Ненюков Д. От Мировой до Гражданской войны. Воспоминания. 1914-1920 / Д. Ненюков. - М.: Кучково поле, 2015. - 759 с.

11. Русская военная эмиграция 20-40-х годов. Документы и материалы. Том 1. Так начиналось изгнание 1920-1922 гг. Книга 1. Исход / Под ред. А. Поскребышева. - М.: Издательство "Гея", 1998. - 426 с.

12. Русселл Дж. Одесская эвакуация (1920) / Дж. Русселл, Р. Кон. - М.: Книга по Требованию, 2012. - 135 с.

13. Савченко В. Дванадцять війн за Україну / Пер. з рос. А. Сопронюка. - К.: Нора-Друк, $2016-480$ c.

14. Савченко В., Файтельберг-Бланк В. Одесса в эпоху войн и революций (1914-1920): [Електрон. pесурс]. - Режим доступу: https:/www.e-reading.club/chapter.php/1043051/20/Savchenko_-_ Odessa_v_epohu_voyn_i_revolyuciy_\%281914_-_1920\%29.html.

15. Стариков Н. В. Русская смута / Н. В. Стариков. - СПб.: Питер, 2017. - 384 с.

16. 1920 год. Одессу охватила паника: [Електрон. ресурс]. - Режим доступу: https://grad.ua/ istoriya-odessy/74238-1920-god-odessu-ohvatila-panika.html.

17. Флот в Белой борьбе / Составление, научная редакция, предисловие и комментарий С. В. Волкова. - М.: ЗАО Центрполиграф, 2002. - 607 с.

18. Шкляев И. Холодная зима 1920 г. в Одессе: [Електрон. ресурс]. - Режим доступу: http:// odesskiy.com/chisto-fakti-iz-zhizni-i-istorii/holodnaja-zima-1920g-v-odesse.html.

19. Штейнман Ф. Отступление от Одессы (январь 1920 г.). Часть 1: [Електрон. ресурс]. - Режим доступу: https://graf-orlov33.livejournal.com/767533.html.

\section{References}

1. Grazhdanskaya voyna v Rossii: oborona Kryma / Sostavitel' V. Goncharov. - M.: OOO "Izdatel'stvo ACT"; SPb.: Terra Fantastica, 2003. - 534 s.

2. Grazhdanskaya voyna v Rossii: Chernomorskiy flot / Sostavitel' V. Dotsenko. - M.: OOO "Izdatel'stvo ACT", 2002. - 544 s.

3. Grazhdanskaya voyna na Ukraine 1918-1920 [v 3-kh tomakh]. Tom 2. Bor'ba protiv denikintsev i petlyurovshchiny (may 1919 - fevral' 1920 gg.) / Pod red. S.M. Korolivskogo. - K.: Izdatel'stvo "Naukova dumka", 1967. - 919 s.

4. Denikin A.I. Ocherki russkoy smuty: [Yelektron. resurs]. - Rezhim dostupu: http://militera.lib. ru/memo/russian/denikin_ai2/5_21.html.

5. Doklad generala N.N. Shillinga generalu A.I. Denikinu: [Yelektron. resurs]. - Rezhim dostupu: https://ru.wikisource.org/wiki/ doklad. 
6. Drozdov S. Evakuatsiya Odessy, 1920 god. Chast' 64: [Yelektron. resurs]. - Rezhim dostupu: https://www.proza.ru/2016/07/29/1217.

7. Istoriya Grazhdanskoy voyny v SSSR [v 5-ti tomakh]. Tom 4. Reshayushchiye pobedy Krasnoy Armii nad ob"yedinennymi silami Antanty i vnutrenney kontrrevolyutsii (mart 1919 - fevral' 1920 gg.) / Pod red. S.F. Naydy, G.D. Obochkina, A.A. Strukova i dr. - M.: Gosudarstvennoye izdatel'stvo politicheskoy lteratury, 1959. - 459 s.

8. Kak ukhodila iz Odessy belaya gvardiya: [Yelektron. resurs]. - Rezhim dostupu: https://odessitua.com/articles/8366-kak-uhodila-iz-odessy-belaya-gvardiya.html.

9. Karpov N. Tragediya Belogo Yuga. 1920 god / N. Karpov. - M.: Veche, 2005 - 375 s.

10. Nenyukov D. Ot Mirovoy do Grazhdanskoy voyny. Vospominaniya. 1914-1920 / D. Nenyukov. - M.: Kuchkovo pole, 2015. - 759 s.

11. Russkaya voyennaya emigratsiya $20-\mathrm{kh}-40-\mathrm{kh}$ godov. Dokumenty i materialy. Tom 1 . Tak nachinalos' izgnaniye 1920-1922 gg. Kniga 1. Iskhod / Pod red. A. Poskrebysheva. - M.: Izdatel'stvo "Geya", 1998. - 426 s.

12. Russell Dzh. Odesskaya evakuatsiya (1920) / Dzh. Russell, R. Kon. - M.: Kniga po Trebovaniyu, 2012. - $135 \mathrm{~s}$.

13. Savchenko V. Dvanadtsyat' víyn za Ukraïnu / Per. z ros. A. Sopronyuka. - K.: Nora-Druk, $2016-480 \mathrm{~s}$.

14. Savchenko V., Faytel'berg-Blank V. Odessa v epokhu voyn i revolyutsiy (1914-1920): [Yelektron. resurs]. - Rezhim dostupu: https://www.e-reading.club/chapter.php/1043051/20/Savchenko_-_ Odessa_v_epohu_voyn_i_revolyuciy_\%281914_-_1920\%29.html.

15. Starikov N.V. Russkaya smuta / N.V. Starikov. - SPb.: Piter, 2017. - 384 s.

16. 1920 god. Odessu okhvatila panika: [Yelektron. resurs]. - Rezhim dostupu: https://grad.ua/ istoriya-odessy/74238-1920-god-odessu-ohvatila-panika.html.

17. Flot v Beloy bor'be / Sostavleniye, nauchnaya redaktsiya, predisloviye i kommentariy S.V. Volkova. - M.: ZAO Tsentrpoligraf, 2002. - 607 s.

18. Shklyayev I. Kholodnaya zima 1920 g. v Odesse: [Yelektron. resurs]. - Rezhim dostupu: http:// odesskiy.com/chisto-fakti-iz-zhizni-i-istorii/holodnaja-zima-1920g-v-odesse.html.

19. Shteynman F. Otstupleniye ot Odessy (yanvar 1920 g.). Chast 1: [Yelektron. resurs]. - Rezhim dostupu: https://graf-orlov33.livejournal.com/767533.html. 
Chirikalov $\boldsymbol{O}$. S., candidate of historical sciences, captain of the 1st rank, associate professor of the department of Naval Forces of the command and staff institute for the use of forces (forces) of the Ivan Chernyakhovsky National Defense University of Ukraine (Kyiv)

\section{ODESSA EVACUATION OF THE "WHITE" MOVEMENT (FORCE) AND CIVIL POPULATION IN FEBRUARY 1920}

Based on materials from published sources, the article comprehensively explores the experience of the preparation and implementation of the evacuation of troops (forces) of the "white" movement and the civilian population from Odessa in February 1920, a historical event from the time of the so-called "Civil War" (1917-1920) on territory of Ukraine.

A detailed analysis by the author of domestic, foreign and Soviet documentary materials, memoirs and publications on this topic indicates that this issue has been little studied - a comprehensive study of the problems has been left unattended by historians, the author has not found a holistic, comprehensive and objective military historical study on this topic. Therefore, there is a need for scientific generalization of the indicated experience in the use of troops (forces) during the preparation and conduct of evacuation activities by sea and the development of naval art, as a theoretical basis for solving scientific and practical problems

The purpose of the proposed article is to disclose and generalize the experience of preparing and conducting the evacuation of troops (forces) of the "white" movement and the civilian population from Odessa in February 1920 to use it in the process of improving the theory and practice of the activities of the Navy of the Armed Forces of Ukraine.

The paper analyzes and explores the main causes and factors that directly affected the preparation and conduct of the Odessa evacuation of troops (forces) of the "white" movement and the civilian population by the sea in February 1920 and, as a result, affected its final results.

The author focuses on the dependence of the results of the Odessa evacuation by sea in February 1920 on such factors as: the views of the leadership of the naval forces on the preparation and use of their forces; preparedness of the military command and control bodies, available fleet forces (including civilian forces) and the region to carry out evacuation tasks by sea; military-geographical conditions 
for the operation of naval forces, including the state and development of the equipment of the theater of operations; the composition and balance of power of the parties and the nature of the action of enemy forces.

The paper highlights and describes the characteristic features of the preparation and conduct of evacuation measures, evaluates the results of their implementation.

Keywords: evacuation of troops (forces) by a sea, troops (forces) of "white" motion, Civil war, Armed forces of South of Russia, Odesa, Odesa evacuation of 1920, Black Sea seat of wars. 